\title{
Antoni Mironowicz, Ks. Michał Bożerianow i jego odpowiedź „ludziom małym”, Wydawnictwo Uniwersytetu w Białym- stoku, Białystok 2015, 131 stron
}

Antoni Mironowicz do swojego bogatego dorobku dotyczącego dziejów prawosławia w Rzeczypospolitej i krajach ościennych dołączył w poprzednim roku bardzo interesującą pracę, która jest poniekąd biografią Białorusina, obywatela II Rzeczypospolitej, duchownego prawosławnego - ks. Michała Bożerianowa w tle której dostrzegamy losy społeczności prawosławnej, białoruskiej na uchodźstwie, ale także w okresie międzywojennym w II Rzeczypospolitej.

Antoni Mironowicz swoją pracą pokazał kolejny obszar badawczy historykom, jakim są losy i działalność Polskiej Autokefalicznej Cerkwi Prawosławnej na uchodźstwie'. Temat w historiografii jest ukazany wyłącznie fragmentarycznie. Powstałe $\mathrm{z}$ reguły na emigracji prace mają charakter wspomnieniowy ${ }^{2}$ i nie odnoszą się szerzej do całości losów prawosławnych uchodźców, którzy zostali rozproszeni po świecie wraz z ewakuacją z Rosji Sowieckiej w 1942 r. Bardzo ubogo, wręcz epizodycznie, są w historiografii przedstawione dzieje duchowieństwa prawosławnego, które, wywiezione z obszarów II Rzeczypospolitej, wraz z duchownymi innych wyznań, spotkał ten sam los. Może był to jeszcze cięższy los z uwagi na to, że społeczność prawosławna była w naturalny sposób kojarzona $\mathrm{z}$ dominacją tej wiary na terenach wywózki. Zapewne przebywając wśród wywiezionych Polaków, mniejszości narodowe, wyznawcy prawosławia z terenów II Rzeczypospolitej, nie wzbudzały wśród nich zaufania. Ksiądz Michał Bożerianow napisał: „pomagałem licznym Polakom. Ale podnieść pragnę,

\footnotetext{
1 Por:: A. Mironowicz, Przyczynek do dziejów Polskiego Prawosławnego Duszpasterstwa Cywilnego na emigracji w czasie II wojny światowej, „Studia Polonijne”, t. 30, Lublin 2009-2010, s. 205-213; idem, Polskie prawostawne duszpasterstwo cywilne w Afryce, „Wiadomości PAKP”, nr 5 (138), Warszawa 2001, s. 12-17; przedruk - M. Szwedziuk, Białorusini w Afryce w latach 1942-1948, „Polski Żołnierz Prawosławny” 1998, R. V, nr 2 (15), s. 14.

2 Ostatnio ukazały się wspomnienia Anny Mironowicz, żony leśniczego z Puszczy Białowieskiej, wywiezionej całą rodziną w pierwszej deportacji w nocy 10 lutego 1940 r.: Od Hajnówki do Pahlavi..., Warszawa 2015, które po raz pierwszy zostały opublikowane w paryskim emigracyjnym wydawnictwie Editions Spotkania w 1986 r.
} 
że często w tym okresie doznawałem krzywd od pewnych byłych urzędników polskich. Ci to właśnie ludzie, chcąc zyskać sobie swoich przełożonych obozu, donosili na mnie o uprawianiu praktyk religijnych nie tylko dla siebie, ale także i innych. Zdaje się, że nie bez głębszego znaczenia jest fakt, iż w tym czasie u mnie, księdza prawosławnego, spowiadali się dwaj księża rzymsko-katoliccy"3. Jakby zapominano, że bezbożny system sowieckiej Rosji szczególnie silnie niszczył duchowieństwo prawosławne na swoim terenie. Uchodźcy w konsekwencji ustaleń gen. Andersa ze Stalinem byli ewakuowani w marcu i lipcu 1942 r. z terenu sowieckiej Rosji. W przeciągu paru tygodni musieli się ewakuować, gdyż w myśl decyzji Stalina z dnia 16 stycznia 1943 r. wszyscy obywatele polscy przebywający w ZSRR byliby odtąd obywatelami sowieckimi. Uchodźcy trafili do Nowej Zelandii ${ }^{4}$, Afryki Wschodniej i Libanu, Indii ${ }^{5}$, Palestyny, Kanady, Meksyku. Stany Zjednoczone odmówiły przyjęcia dzieci uchodźców, wynikało to z chęci zachowania sojuszu ze Stalinem, który podpisano w Jałcie. Z sowieckiej Rosji ewakuowało się 41 tysięcy wojskowych oraz 74 tysiące ludności cywilnej, głównie kobiety i dzieci.

Pierwszą miejscowością, do której trafili uchodźcy była Pahlavi w Iranie ${ }^{6}$, a najwięcej zostało skierowanych do Teheranu i Isfahanu. 4701 osób ewakuowano do Indii, a następnie do obozu w Tengeru w Tanzanii, ówczesnej Tanganice, wśród nich był ks. Michał Bożerianow. Z kolei inna grupa została ewakuowana do Ugandy, Kenii i RPA. Łącznie w Afryce Wschodniej było najwięcej uchodźców - 23 676, w Palestynie - 6569, w Meksyku - 1 569, w Nowej Zelandii -838 , a pozostali do innych wyżej wymienionych krajów. Antoni Mironowicz podkreśla, że najwięcej informacji o Białorusinach uchodźcach pochodzi właśnie z grupy, która trafiła do Afryki Wschodniej. Podaje, że w październiku 1942 r. do Afryki z Iranu wyjechało około 900 obywateli polskich wyznania prawosławnego. Ponadto w kwietniu 1943 r. w Obozie Uchodźców Polskich nr 1 w Iranie przebywało jeszcze około 800 osób wyznania prawosławnego 7 . Przypuszczam, że są to zaniżone dane, bowiem istniała grupa dzieci wyznania prawosławnego po-

3 A. Mironowicz, Ks. Michał Bożerianow i jego odpowiedź „ludziom małym”, Wydawnictwo Uniwersytetu w Białymstoku, Białystok 2015, s. 98-99.

${ }^{4}$ Por. Dwie ojczyzny. Polskie dzieci w Nowej Zelandii. Tułacze wspomnienia, przekł. z języka angielskiego: S. Manterys, S. Zawada, A. Szatkowska, Warszawa 2006.

5 Por. Polacy $w$ Indiach 1942-1948 w świetle dokumentów $i$ wspomnień, red. L. Betgowski, Warszawa 2002.

6 Por. Polacy w Iranie 1942-1945, t. I: Antologia, red. A. Kunert, A. Przewoźnik, Warszawa 2002.

7 A. Mironowicz, Ks. Michał Bożerianow..., s. 55; por.: J. Grzybowski, Białorusini wśród uchodźców polskich na Środkowym Wschodzie i w Afryce Wschodniej w czasie II wojny światowej, „Pamięć i Sprawiedliwość" 2005, nr 2; idem, Biatorusini w polskich regularnych formacjach wojskowych w latach 1918-1945, Warszawa 2006; D. Boćkowski, Deklaracja obywateli polskich narodowości białoruskiej dla gen. Władysława Sikorskiego, „Mazowieckie Studia Humanistyczne”, R. II, nr 2, Łowicz 1996. 
zostawiona bez rodziców, która uległa wychowaniu w wierze rzymskokatolickiej. Działo się to w warunkach, gdy w obozie byli jedynie księża rzymskokatoliccy. Wtenczas dzieciom tym spolszczano nazwiska, które miały końcówki wschodnie.

Źródłem, które poddał analizie Antoni Mironowicz w książce, jest niewielka broszura autorstwa ks. Michała Bożerianowa pod tytułem Moja odpowiedź „ludziom małym”, wydana w 1945 r. w Afryce, w Tengeru koło Arushy w Tanzanii, a napisana i podpisana przez ks. Michała Bożerianowa jako ówczesnego Prawosławnej Cerkwi Inspektora Religijnego na Centralną i Wschodnią Afrykę . $^{\circ}$ Niezbyt obszerne źródło jest z kolei bogatym materiałem wnoszącym do badań nad społecznością prawosławną w latach 1939-1945 wiele istotnych faktów. Poznajemy fakty z życia ks. Michała Bożerianowa, ale także dostrzegamy stosunek Białorusinów do państwa polskiego, zarówno w okresie międzywojennym, jak i do Emigracyjnego Rządu Polskiego w Londynie. Czy też na odwrót - stosunek władz polskich i ludności polskiej do mniejszości narodowych i wyznaniowych (obywateli II Rzeczypospolitej) w okresie międzywojennym i w czasie wojny na uchodźstwie. Broszura ks. Michała Bożerianowa ma bardzo osobisty, emocjonalny charakter, w której wiele wątków jest pominiętych, chociażby ten, w jakich okolicznościach został wywieziony do łagrów przez władze sowieckie i jak wyglądało życie w łagrach. Ksiądz pisze niewiele: „Po okupacji terenu Polski w roku 1939 zostaje aresztowany. Tak rozpoczynam nowy okres swego życia, okres więzień, badań, przesłuchiwań i wreszcie łagrów"9. Może ma to jakieś osobiste podłoże, gdyż nie wspomina prawie swojej żony ani dzieci. Jest zachowany fakt z czasu ewakuacji z Rosji: „W momencie, kiedy otrzymałem listy pełne uznania i podziękowania za moje obywatelskie stanowisko, w tym samym momencie, jak gdyby na ironię, żona moja zostaje brutalnie wyrzucona z transportu obywateli polskich, mających być ewakuowanymi z Rosji do Iranu. Pozostaje więc w Rosji. Pozostaje dlatego, że jest prawosławną i że jest żoną «popa prawosławnego»"10. Większość wspomnień uchodźców skupia się właśnie na ich pobycie $\mathrm{z}$ rodzinami w łagrach. Znacznie więcej dowiadujemy się o życiu na uchodźstwie po wyjściu w 1942 r. z ZSRR, poczynając od marca 1942 i przybycia do Pahlavi w Persji. Antoni Mironowicz szczególnie ten wątek poddał analizie.

Po krótkim pobycie w Pahlavi ks. Michał Bożerianow przebywał w Teheranie, gdzie odprawiał regularnie nabożeństwa w zorganizowanej przez siebie kaplicy w Obozie Uchodźców Polskich nr 2. W marcu 1942 r. właśnie tam rozpoczął działalność Polski Prawosławny Kościół Autokefaliczny. Zwierzchnikiem duszpasterstwa prawosławnego w Wojsku Polskim w 1942 r. został Sawa Sowie-

8 M. Bożerianow, Moja odpowiedź „,ludziom małym”, Tengeru, Arusha, Tanganika, 1945.

9 A. Mironowicz, Ks. Michat Bożerianow..., s. 98.

10 Ibidem, s. 120. 
tow ${ }^{11}$, który był mocno podbudowany działalnością duszpasterską na uchodźstwie ks. Michała Bożerianowa. Ogólna liczba prawosławnych w Teheranie w październiku 1942 r. wynosiła 1650 osób, ponadto była znaczna część Białorusinów, która ukrywała wyznanie i podawała się za Polaków-katolików ${ }^{12}$. W Teheranie ks. Michał Bożerianow, oprócz tworzenia życia parafii prawosławnej, również powołał Komitet Białoruski, na czele którego sam stanął. Na obu polach działalność księdza była znacząca, m.in. prowadził działalność wydawniczą (wydając „Ziarnko Prawosławne” czy „Modlitewnik Prawosławny”), zaangażowany był we wprowadzenie Białorusinów do Rady Narodowej ${ }^{13}$. W końcu marca 1943 r. ks. Michał Bożerianow wraz z wiernymi zdecydował się na wyjazd do Afryki, do Tanzanii. Ksiądz przybył do Tengeru w lipcu 1943 r., gdzie był jedynym duchownym prawosławnym na terenie polskich osiedli w Afryce. Wówczas został przez władze duchowne powołany na stanowisko Inspektora Religijnego na Centralną i Wschodnią Afrykę Prawosławnej Cerkwi Polskiej. W Afryce kontynuował znacznie już bardziej rozwiniętą działalność wydawniczą i duszpasterską (m.in. w Nairobi w 1944 r. wydał kolejny „Modlitewnik prawosławny” dzięki wsparciu finansowemu Konsula Generalnego RP w Nairobi, a słowo wstępne napisał legat patriarchy aleksandryjskiego i całej Afryki, Christoforosa II - archimandryta Filotheos Hierides). Ksiądz Michał Bożerianow do końca życia (zmarł 20 sierpnia 1946 r. w obozie w Tengeru w 1946 r.) był zaangażowany we współpracę z rządem polskim. Antoni Mironowicz podkreśla, że ks. Michał Bożerianow „widział we współpracy z rządem polskim szansę na odzyskanie niepodległości i odbudowę kraju, w którym Białorusini, Polacy i inne mniejszości mieliby takie same prawa. (...) Rząd polski na uchodźstwie nie zwracał uwagi na opinie obywateli polskich narodowości białoruskiej w udowodnieniu swych pretensji do ziem Zachodniej Białorusi. Dla rządów zachodnich, w warunkach toczącej się wojny, problem białoruski nie stanowił istotnego znaczenia. Uważano w przyszłości, że ziemie białoruskie będą stanowić problem wewnętrzny ZSRR. Wrogo do duchowieństwa prawosławnego i działalności Komitetu Białoruskiego odnosiło się środowisko polskich uchodźców"14.

Książka Antoniego Mironowicza przybliża nam postać ks. Michała Bożerianowa, którego praca duszpasterska wśród uchodźców, szczególnie narodowości białoruskiej, była znacząca, a w historiografii mało znana. Ponadto, zaangażowanie duchownego w spawy narodowe i państwowe ukazuje silny związek społeczności białoruskiej, prawosławnej, z państwowością polską.

11 Por. Arcybiskup generat brygady Sawa (Jerzy Sowietow). Wybór dokumentów, oprac. K. Filipow, A. Suchcitz, Białystok - Warszawa 1997.

12 J. Grzybowski, Białorusini $w$ polskich regularnych formacjach wojskowych $w$ latach 1918-1945, s. 368; A. Mironowicz, Ks. Michat Bożerianow..., s. 28.

13 A. Mironowicz, Ks. Michat Bożerianow..., s. 30-55.

14 Ibidem, s. 69-70. 